\title{
Secondary Literacy Across the Curriculum: Challenges and Possibilities
}

\author{
Stephen May and Noeline Wright \\ School of Education, University of Waikato, New Zealand
}

This paper discusses the challenges and possibilities attendant upon successfully implementing literacy across the curriculum initiatives - or 'school language policies' as they have come to be known-particularly at the secondary or high school level. It provides a theoretical background to these issues, exploring previous academic discussions of school language policies, and highlights key areas of concern as well as opportunity with respect to school implementation of such policies. As such, it provides a necessary conceptual background to the subsequent papers in this special issue, which focus upon the Secondary Schools' Literacy Initiative (SSLI) - a New Zealand funded programme that aims to establish cross-curricular language and literacy policies in secondary schools.

doi: $10.2167 / l e 797.0$

Keywords: school language policies, language across the curriculum, literacy, secondary schools, whole school, pedagogical content knowledge

\section{Introduction}

It is hard ... to kick against the pricks.

Acts 26:14 (King James Version)

As with God's admonition to Saul (subsequently, the Apostle Paul) in the Christian New Testament, implementing literacy across the curriculum policies often seems like an uphill, sometimes overwhelming, battle. These crosscurricular 'school language policies', as they have come to be known, aim to address 'the particular language needs of a school' (May, 1997: 229). Such policies should identify 'areas within school organisation, curriculum, pedagogy and assessment where specific language needs exist' and indicate directions and methods for dealing with specific issues 'within a discretionary and flexible framework' that also includes mechanisms for review and monitoring (May, 1997: 229; see also Corson, 1990, 1999; Wright, in press). At one level, this seems straightforward. And yet, despite a considerable amount of discussion on the benefits of such policies, beginning over 40 years ago with the Dartmouth Conference in England on Language Across the Curriculum (LAC; see below), there is still much that needs to be done before this becomes a regular feature of school organisation, pedagogy and practice. This is even more apparent in the secondary or high school context, where the traditional organisation of secondary schools often specifically militates against whole school, cross-curricular initiatives such as these (see May; Smyth, this issue for further discussion). 
Before turning to the particular organisational challenges facing school language policies, particularly in the secondary school context, it is important to briefly review the relevant literature. There are two key points of focus here:

(1) How an initial enthusiasm for school-based cross-curricular language policies has waned in the current era of high-stakes testing?

(2) The theory/practice disjuncture, with the strong theoretical advocacy of school language policies undermined by its desultory implementation in schools themselves (particularly, secondary schools).

\section{A Sign of the Times? From Cross-curricular to Compartmentalised Curriculum and Assessment in Schools}

The Language Across the Curriculum (LAC) movement, beginning with the Dartmouth Conference in 1966 in England, was the initial impetus for the development of school language policies (Barnes et al., 1969). As summarised by May (1997: 230), the major tenets of LAC were that:

- language has a central role in learning;

- students need to be actively engaged in meaning-making;

- teachers need to foster student-centred learning (as opposed to didactic approaches);

- active learning involves four key modes of language: reading, writing, speaking and listening, and

- students' own language should be the principal tool for working through curriculum content.

LAC ideas quickly spread to other countries, including New Zealand. One of LAC's attractions at the time was its emphasis on learning rather than teaching, centring attention on students. A key implication was that teachers had to move away from being the central focus of the classroom, to a position in which they encouraged students to use their own language to make sense of their developing learning. This growing enthusiasm for student-centred and collaborative learning methods was supported during the 1970s and 1980s by wider school-based approaches to curriculum development (see, for example, Skilbeck, 1984; Smyth, 1989, 1991; Stenhouse, 1975), in which schools were seen as the 'principal site of curriculum change and teachers [as] key curriculum innovators' (May, 1997: 231). It was also supported by the emergence in the USA of the whole-language movement (Goodman, 1982, 1989), which provided comparable emphases on whole language activities and student-centred learning.

It was primarily through the work of the late David Corson (see especially 1990, 1999), however, that the idea of cross-curricular school language policies began to take hold theoretically. Corson extended 'the conception of language to include not only the four conventional language modes, but also the additional activities of moving, watching, shaping, and viewing' (May, 1997: 232). Corson also, crucially, extended the original LAC focus to include 'second language, bilingual, foreign language and wider social justice issues' (see 1990, 1993, 1999), acknowledging the greater multiethnic nature of many schools worldwide (see also May, 1994a, 1994b). 
But the enthusiasm for these kinds of cross-curricular initiatives has also withered worldwide in the face of the (re-)emergence of high-stakes testing, and the preoccupation in many countries with a narrow, technicist view of literacy, alongside an increasingly rigid compartmentalisation of curricula and the related de-skilling of the teaching profession (Abedi, 2004; Amrein \& Berliner, 2002; Apple, 1993; see also Smyth; Whitehead, this issue). These are difficult times indeed for holistic, whole-school, cross-curricular literacy polices, particularly in a wider context that also demands almost immediate, quantifiable results with respect to changes in student achievement. As we shall see in this special issue, the key feature of developing effective approaches to literacy across the curriculum is that it simply takes time, with significant implications for, and a myriad of changes required to the traditional organisation, pedagogy and practice of schools (May, this issue; Taylor et al., 2005).

\section{From Theory to Practice: Bridging the Divide}

Be that as it may, this should not disguise the fact that-even in its theoretical heyday - schools actually implemented such whole-school, cross-curricular language policies far less than advocates of school language policies would have wished (see Corson, 1990, 1999; May, 1994b, 1997 for further discussion). As Wells (1991: 1) observed of the early LAC movement: 'LAC has remained a slogan to rally the converted rather than a policy that is affecting the daily practice of the majority of teachers and administrators across all levels of the education [system]...'. This discrepancy between theory and practice is further illustrated by Corson's (1990: 1) observation that school language policies 'are increasingly viewed by a growing number of educationists as an integral and necessary part of the administrative and curriculum practices of modern schools, yet relatively few schools anywhere have seriously tackled the problem of introducing them'.

A number of key reasons can be ascertained for the desultory implementation of school language policies. First, while official support for school language policies has been forthcoming at a national level in a number of countries, particularly Britain, financial resources in support of these policies generally have not. The New Zealand Secondary Schools' Literacy Initiative (SSLI), which is the focus of this special issue of Language and Education, is a notable exception in this regard, and demonstrates just what can be achieved when targeted resourcing and support for literacy across the curriculum are prioritised and made available to schools.

Second, where the implementation of school language policies has been attempted in schools - and despite a range of practical suggestions offered in the literature (see Corson, 1990, 1999) - numerous operational difficulties have ensued. The most common reasons for experiencing difficulties in implementation have centred on three key areas:

- a lack of acceptance and agreement in schools over the aims and scope of a school language policy;

- an inability to involve all teachers (let alone the wider school community) in the development of the policy, thus ensuring support for the policy;

- an inability to change school structures to match the inclusive intentions with which school language policies have been largely associated. 
In relation to these difficulties, the issue of teacher 'buy-in' is crucial, and the level of buy-in from teachers is largely dependent on the nature of the process undertaken in implementing a school language policy. In short, a school language policy needs to be both carefully thought through and carefully managed if all staff are to be convinced of its merits. In particular, the following factors have been identified as essential to the successful implementation of a school language policy: (1) the central involvement of school management; (2) sufficient time and resources to effect real change; and (3) the crucial role of staff development in providing initial and ongoing support (May, 1997). All these factors are demonstrably evident with respect to the SSLI initiative canvassed in this special issue, as subsequent papers will make clear.

Another key issue here is the significance of staff professional development (PD) and its ability to provide teachers with a theorised approach to the implementation of literacy across the curriculum. Teachers have to have a sufficient basis in theory in order to understand the educational intentions involved in school language policy development and to be able to implement them effectively (Corson, 1990, 1999; Marland, 1977). As Corson (1990: 84-85) observes of this, 'teachers need to be given greater access to theory, which is professional knowledge about the processes of language and learning, coupled with better information about what children can be expected to do and what they are doing in progressive settings'.

A final obstacle to the successful implementation of school language policies relates again to its educational intentions. As the preceding discussion highlights, it is important that teachers understand these intentions fully and that they are actively involved in implementing them, but this in itself is not enough. School structures also need to be changed in order to reflect the inclusive and (potentially) emancipatory concerns of school language policies. Specifically, developing a successful school language policy requires the school to have the following characteristics:

More democratic: Organisationally, the formulation and implementation of school language policies should ideally involve all teachers in the decisionmaking process. An additional benefit, as Corson (1990: 59) suggests, is that 'schools collaboratively managed [in this way], and with agreed and working policies, are more likely to be places of staff and community commitment'.

Critically reflective: The key tenets of school language policies require a 'radical rethinking of the way in which the triangular relationship between learning, teaching and the curriculum is understood, particularly in the context of a multicultural/multilingual society' (Wells, 1991: 2). Put more simply, school language policies require major changes to teacher attitudes and the pedagogical choices they make (Corson, 1990, 1999). Schools thus need to promote critical educational reflection, as an integral part of school language policy development, so as to accomplish the degree of 'radical rethinking' required (May, 1994b).

Whole-school oriented: School language policies need to be both cross-curricular in themselves and to be closely integrated with other curriculum policies (Corson, 1990, 1999; May, 1994a, 1994b). This is not easy when many schools, particularly at the secondary level, remain compartmentalised, constrained 
within (often) rigid subject boundaries. As Marland (1977) observed presciently, over 30 years ago now, the key problem many schools (still) have in implementing a school language policy is in first finding a curriculum across which to put it.

\section{Addressing the Secondary School Context}

If the general issues raised by school language policies are necessarily complex and demanding in relation to their successful implementation in schools, these concerns and/or difficulties are inevitably exacerbated in secondary or high school contexts (Knott, 1985; Moje et al., 2000; O'Brien et al., 1995; Torbe, 1980). A principal reason has to do with the clearly demarcated subject orientation of secondary schooling, just discussed, which results in many subject-based teachers 'resisting' the whole-school aims of a literacy policy, assuming these to be the 'preserve' of the English department. Wells (1991) comments, for example, on the widespread perception among secondary school teachers that the development of an integrated, cross-curricular school literacy policy is either an act of imperialism on the part of English teachers, or their attempt to avoid responsibility for ensuring their students' continued language development! Conversely, Proctor (1987) observes that some English subject teachers oppose whole-school literacy policies because of their potential to 'dilute' the academic content of their own subject area.

Closely allied with these attitudes is an ongoing hierarchisation of secondary school subjects and a related privileging of curriculum content over pedagogical process by many secondary school teachers. As Goodson (1983: 3) has argued, curricular disputes in secondary schools most often focus on 'status, resources and territory', with so-called high-status subjects such as mathematics and science protecting their rights, privileges and power by actively working to maintain conceptions of their subjects as distinct, difficult and important $\left(\mathrm{O}^{\prime}\right.$ Brien et al., 1995). This often confounds attempts to establish cross-curricular school language policies in secondary schools. Even in Secondary English Departments themselves, there is a tendency still for English teachers to assume that students' literacy is something which should already be well established by the time such students reach secondary school and, if it is not, that it is 'not their problem' (May, 2002). As Gunderson (2000: 692) has observed, from a North American perspective, 'it has been known for some time that secondary teachers do not consider reading and learning to read as issues that are of much importance to them.'

Gunderson's observation usefully highlights perhaps the greatest ongoing challenge for secondary school teachers in relation to school language policies - their relative lack of literacy pedagogical content knowledge (PCK), and related student-centred pedagogical practices and learning-to-learn strategies (May, 1997; Moje et al., 2000; O'Brien et al., 1995). Certainly, they are generally far less well equipped than their primary (elementary) school colleagues with respect to addressing overtly and deliberately the specific literacy demands of their teaching and learning contexts, and the related texts and textual practices that they use with their students. Relatedly, while secondary schools are often extremely diligent about collecting summative, standardised data on student 
literacy achievement, they are generally much less able to analyse these data formatively and diagnostically - as a basis for informing, and where necessary changing, classroom teaching and learning practices (Taylor et al., 2005; see also May; Whitehead, this issue). And yet this is precisely why major cross-curricular PD, focussed on literacy PCK, a diagnostic approach to student literacy achievement, and the related organisational and pedagogical changes that flow from these, are so desperately needed in secondary schools.

\section{Conclusion}

O'Brien et al. (1995) in their equivalent discussion over a decade ago now of what they termed 'content literacy' approaches, came to the following conclusion as to why they were still so rare in secondary schools:

... content literacy, as a radical pedagogy, confronts deeply embedded values, beliefs, and practices that teachers, students, and other members of the school culture hold. Specifically, it challenges content subject primacy, teacher control, and knowledge dissemination, calling instead for student independence and knowledge construction. Content literacy, with its focus on multiple and diverse texts, active engagement in learning, studentcentered instruction, and social construction, is antithetical to the dominant [secondary] school culture. (1995: 454)

Sadly, this conclusion still broadly holds in many secondary schools today. However, the remainder of this special issue of Language and Education outlines the key issues that emerge when a 'content literacy' or cross-curricular school language policy is specifically fostered in secondary schools by targeted, funded and facilitated professional development - in this case, the New Zealand-based Secondary Schools' Literacy Initiative (SSLI). In doing so, we hope that the discussion within these pages will provide a useful point of reference as well as a basis for future possibilities for other national contexts. We also hope that it may go some way to re-establishing the importance of, and need for crosscurricular school language policies in a curriculum and assessment era which, in its quest for 'improved student literacy outcomes', has ironically undermined the very pedagogical processes best placed to achieve them.

\section{Correspondence}

Any correspondence should be directed to Professor Stephen May, School of Education, University of Waikato, Private Bag 3105, Hamilton 3240, New Zealand (s.may@waikato.ac.nz).

\section{References}

Abedi, J. (2004) The no child left behind act and English language learners: Assessment and accountability issues. Educational Researcher 33 (1), 4-15.

Amrein, A. and Berliner, D. (2002) High-stakes testing, uncertainty and student learning. Education Policy Analysis Archives 10 (8). http://epaa.edu/epaa/v10n18/. Accessed 31.03.07.

Apple, M. (1993) The politics of official knowledge: Does a national curriculum make sense? Teachers College Record 95, 222. 
Barnes, D., Britton, J. and Rosen, H. (1969) Language, the Learner and the School. London: Penguin Education.

Corson, D. (1990) Language Policy Across the Curriculum. Clevedon: Multilingual Matters.

Corson, D. (1993) Language, Minority Education and Gender. Clevedon: Multilingual Matters.

Corson, D. (1999) Language Policy in School: A Resource for Teachers and Administrators. Mahwah, NJ: Lawrence Erlbaum Associates.

Goodman, K. (1982) Language and Literacy: The selected Writings of Kenneth S. Goodman. London: Routledge and Kegan Paul.

Goodman, K. (1989) Whole language research: Foundations and development. Elementary School Journal 90, 207.

Goodson, I. (1983) School Subjects and Curriculum Change. London: Croom Helm.

Gunderson, L. (2000) Voices of the teenage diasporas. Journal of Adolescent and Adult Literacy $43,692$.

Knott, R. (1985) The English Department in a Changing World. Milton Keynes: Open University Press.

Marland, M. (1977) Language Across the Curriculum. London: Heinemann.

May, S. (1994a) Making Multicultural Education Work. Clevedon: Multilingual Matters.

May, S. (1994b) School-based language policy reform: A New Zealand example. In A. Blackledge (ed.) Teaching Bilingual Children (pp. 19-41). London: Trentham Press.

May, S. (1997) School language policies. In R. Wodak and D. Corson (eds) Encyclopedia of Language and Education. Language Policy and Political issues in Education (Vol. 1, pp. 229-240). Dordrecht: Kluwer.

May, S. (2002) The problem with literacy. English in Aotearoa 48, 4.

Moje, E., Dillon, D. and O'Brien, D. (2000) Re-examining roles of learner, text, and context in secondary literacy. Journal of Educational Research 93, 165.

O'Brien, D., Stewart, R. and Moje, E. (1995) Why content literacy is difficult to infuse into the secondary school: Complexities of curriculum, pedagogy and school culture. Reading Research Quarterly 30, 442.

Proctor, N. (1987) Bullock refreshed: The five languages for life. Reading 21, 80.

Skilbeck, M. (1984) School-based Curriculum Development. London: Harper and Row.

Smyth, J. (1989) Critical Perspectives on Educational Leadership. London: Falmer Press.

Smyth, J. (1991) Teachers as Collaborative Learners: Challenging Dominant Forms of Supervision. Milton Keynes: Open University Press.

Stenhouse, L. (1975) An Introduction to Curriculum Research and Development. London: Heinemann.

Taylor, B., Pearson, P., Petersen, D. and Rodriguez, M. (2005) The CIERA framework: An evidence-based approach to professional development and school reading improvement. Reading Research Quarterly 40, 40.

Torbe, M. (1980) Language Policies in Action: Language Across the Curriculum in Some Secondary Schools. London: Ward Lock.

Wells, G. (1991) Learning and Teaching the Discourses of the Disciplines. Toronto: The author.

Wright, N. (in press) School language policies. In S. May and N. Hornberger (eds) Language Policy and Political Issues in Education. Encyclopedia of Language and Education (2nd edn), (Vol. 1, in press). Dordrecht: Kluwer. 